Fixed Point Theory, 21(2020), No. 2, 647-656

DOI: $10.24193 /$ fpt-ro.2020.2.45

http://www.math.ubbcluj.ro/ nodeacj/sfptcj.html

\title{
ON BEST PROXIMITY PAIRS WITH APPLICATION TO DIFFERENTIAL EQUATIONS
}

\author{
G. SANKARA RAJU KOSURU
}

Department of Mathematics, Indian Institute of Technology Ropar Ropar - 140 001, Punjab, India E-mail: raju@iitrpr.ac.in

Abstract. In this paper we consider the following system of differential equations,

$$
y^{\prime}=f(x, y), y\left(x_{0}\right)=y_{1} \text { and } z^{\prime}=g(x, z), z\left(x_{0}\right)=z_{1},
$$

where $f, g$ are bounded $L^{1}$ functions defined on a rectangle in $\mathbb{R}^{2}$. We give sufficient conditions for the existence of two functions $\phi$ and $\psi$, on an interval $I$ containing $x_{0}$, such that

$$
\begin{gathered}
\left|y_{1}+\int_{x_{0}}^{x} f(t, \phi(t)) d t-\phi(x)\right| \leq\left|y_{1}-z_{1}\right|, \\
\left|z_{1}+\int_{x_{0}}^{x} g(t, \psi(t)) d t-\psi(x)\right| \leq\left|y_{1}-z_{1}\right|
\end{gathered}
$$

for all $x \in I$. To establish the same, we introduce a notation of c-cyclic contractive mapping and prove the existence of best proximity pairs for such a mapping.

Key Words and Phrases: Contraction, best proximity points, system of differential equations. 2010 Mathematics Subject Classification: 47H10, 54H25.

Acknowledgement. The author would like to thank the anonymous reviewers for their suggestions and comments.

\section{REFERENCES}

[1] E.A. Coddington, N. Levinson, Theory of Ordinary Differential Equations, McGraw-Hill Book Company, Inc., New York, 1955.

[2] A.A. Eldred, W.A. Kirk, P. Veeramani, Proximal normal structure and relatively nonexpansive mappings, Studia Math., 171(2005), no. 3, 283-293.

[3] A.A. Eldred, P. Veeramani, Existence and convergence of best proximity points, J. Math. Anal. Appl., 323 (2006), no. 2, 1001-1006.

[4] A.A. Eldred, P. Veeramani, On best proximity pair solutions with applications to differential equations, J. Indian Math. Soc. (N.S.) 2007, Special Volume on the Occasion of the Centenary Year of IMS (1907-2007), 51-62.

[5] R. Espínola, A new approach to relatively nonexpansive mappings, Proc. Amer. Math. Soc., 136 (2008), no. 6, 1987-1995.

[6] K. Fan, Extensions of two fixed point theorems of F.E. Browder, Math. Z., 112(1969), 234-240.

[7] W.A. Kirk, S. Reich, P. Veeramani, Proximinal retracts and best proximity pair theorems, Numer. Funct. Anal. Optim., 24 (2003), no. 7-8, 851-862. 
[8] S. Sadiq Basha, P. Veeramani, Best proximity pair theorems for multifunctions with open fibres, J. Approx. Theory, 103(2000), no. 1, 119-129.

[9] G. Sankara Raju Kosuru, Extensions of Edelstein's theorem on contractive mappings, Numer. Funct. Anal. Optim., 36(2015), no. 7, 887-900.

[10] G. Sankara Raju Kosuru, P. Veeramani, On existence of best proximity pair theorems for relatively nonexpansive mappings, J. Nonlinear Convex Anal., 11(2010), no. 1, 7.

[11] G. Sankara Raju Kosuru, P. Veeramani, A note on existence and convergence of best proximity points for pointwise cyclic contractions, Numer. Funct. Anal. Optim., 32(2011), no. 7, 821-830.

[12] G. Sankara Raju Kosuru, P. Veeramani, Cyclic contractions and best proximity pair theorems, J. Optim. Theory Appl., 164(2015), no. 2, 534-550.

[13] I. Singer, Best Approximation in Normed Linear Spaces by Elements of Linear Subspaces, Die Grundlehren der Mathematischen Wissenschaften, Band 171 Publ. House Acad. SR Romania, Bucharest, 1970.

[14] T. Suzuki, M. Kikkawa, C. Vetro, The existence of best proximity points in metric spaces with the property UC, Nonlinear Anal., 71(2009), no. 7-8, 2918-2926.

Received: October 16, 2019; Accepted: December 23, 2019. 
ON BEST PROXIMITY PAIRS 